\title{
Hydrogen Generation During the Corrosion of Carbon Steel in Oxalic Acid \\ (U)
}

\author{
B. J. Wiersma \\ Savannah River National Laboratory \\ Strategic Materials Technology Department \\ Materials Technology Section
}

Publication Date: August 2004

Patent Status

This internal management report is being transmitted without DOE patent clearance, and no further dissemination or publication shall be made of the report without prior approval of the DOE-SR patent counsel.

\section{Westinghouse Savannah River Company Savannah River Site Aiken, SC 29808}

This document was prepared in connection with work done under Contract No. DE-AC09-96SR18500 with the U. S. Department of Energy 
This document was prepared in conjunction with work accomplished under Contract No. DE-AC09-96SR18500 with the U. S. Department of Energy.

\section{DISCLAIMER}

This report was prepared as an account of work sponsored by an agency of the United States Government. Neither the United States Government nor any agency thereof, nor any of their employees, makes any warranty, express or implied, or assumes any legal liability or responsibility for the accuracy, completeness, or usefulness of any information, apparatus, product or process disclosed, or represents that its use would not infringe privately owned rights. Reference herein to any specific commercial product, process or service by trade name, trademark, manufacturer, or otherwise does not necessarily constitute or imply its endorsement, recommendation, or favoring by the United States Government or any agency thereof. The views and opinions of authors expressed herein do not necessarily state or reflect those of the United States Government or any agency thereof.

This report has been reproduced directly from the best available copy.

Available for sale to the public, in paper, from: U.S. Department of Commerce, National Technical Information Service, 5285 Port Royal Road, Springfield, VA 22161, phone: (800) 553-6847, fax: (703) 605-6900

email: orders@ntis.fedworld.gov

online ordering: http://www.ntis.gov/help/index.asp

Available electronically at http://www.osti.gov/bridge

Available for a processing fee to U.S. Department of Energy and its contractors, in paper, from: U.S. Department of Energy, Office of Scientific and Technical Information, P.O. Box 62, Oak Ridge, TN 37831-0062,

phone: (865)576-8401,

fax: (865)576-5728

email: $\underline{\text { reports@ adonis.osti.gov }}$ 


\section{SMTD}

Strategic Materials Technology Department

Keywords: Corrosion,

Chemistry, Waste Tank

Retention - Permanent

\section{Hydrogen Generation During the Corrosion of Carbon Steel in Oxalic Acid}

by

B. J. Wiersma

SRNL SAVANNAH RIVER NATIONAL LABORATORY, AIKEN, SC 29808 Westinghouse Savannah River Company

Prepared for the U. S. Department of Energy under Contract DE-AC09-96SR18500 
This page was intentionally left blank 


\section{Hydrogen Generation During the Corrosion of Carbon Steel in Oxalic Acid}

\subsection{Summary}

A literature review of the corrosion mechanism for carbon steel in oxalic acid was performed to determine the ratio of moles of iron corroded to moles of hydrogen evolved during the corrosion of iron in oxalic acid. The theory of corrosion of carbon steel in oxalic acid and experimental work were reviewed. It was concluded that the maximum ratio of moles of hydrogen evolved to moles of iron corroded is 1:1. This ratio would be observed in a de-aerated environment. If oxygen or other oxidizing species are present, the ratio could be much less than 1:1. Testing would be necessary to determine how much less than 1:1 the ratio might be.

Although the ratio of hydrogen evolution to iron corroded will not exceed 1:1, the total amount of hydrogen evolved can be influenced by such things as a decrease in the exposed surface area, suppression of hydrogen generation by gamma radiation, the presence of corrosion products on steel surface, etc. These and other variables present during chemical cleaning operations of the waste tank have not been examined by the tests reported in the literature i.e., the tests have focused on clean corrosion coupons in oxalic acid solutions. It is expected that most of these variables would reduce the total amount of hydrogen evolved. Further testing would need to be performed to quantify the reduction in hydrogen generation rate associated with these variables.

\subsection{Background}

Oxalic acid has been proposed for chemical cleaning of residual sludge heels from high level waste tanks. The acidic conditions will result in corrosion of the carbon steel waste tank. Hydrogen evolution may also accompany the corrosion of iron in an acidic solution. Given the significant amount of carbon steel surface area in the tank, the concentration of hydrogen in the tank vapor space could rapidly approach the limit, unless purge ventilation were continuously operable. Ensuring that the purge ventilation is continuous could impact the cost and schedule of the chemical cleaning reactions.

This document summarizes a literature review that was performed to gain a more complete understanding of the hydrogen evolution reaction that occurs during the corrosion of carbon steel in oxalic acid. The theory of carbon steel corrosion in oxalic acid was presented as well as the supporting experimental work that was performed. Finally the application of the theory and test results to chemical cleaning at SRS are discussed. 


\subsection{Corrosion Mechanism Theory}

Corrosion is a process that involves electrochemical as well as chemical reactions. The electrochemical reactions differ from the chemical reactions in that an exchange of electrons occurs at the interface between the metal and the solution. In order to maintain a balance of charge, two reactions occur at the surface. The metal dissolution reaction, or anodic reaction, results in the loss of electrons, while the coupled cathodic reaction results in a species gaining electrons. An example of these two reactions is shown in equations 1 and 2, where iron is being oxidized to ferrous species while hydrogen ions are being reduced such that hydrogen is evolved.

$\mathrm{Fe}^{\circ} \longrightarrow \mathrm{Fe}^{2+}+2 \mathrm{e}^{-}$

$2 \mathrm{H}^{+}+2 \mathrm{e}^{-} \longrightarrow \mathrm{H}_{2} \uparrow$

The $\mathrm{pH}$ and oxidizing power of a given environment determines whether a species is thermodynamically stable in a given environment as shown by Pourbaix diagrams (see Figures 1 and 2) [1-3]. These potential (E)-pH diagrams present a map of the regions of stability of a metal and its corrosion products in an aqueous environment. The diagrams also identify conditions under which 1) the metal is stable and will not corrode, 2) soluble reaction products are formed and corrosion will occur, and 3 ) insoluble reaction products are formed and passivity will occur. The Pourbaix diagram assists in determing which corrosion reactions are possible in a given aqueous environment.

In dealing with the stability of metals in aqueous solutions, the thermodynamic stability of water is essential to an understanding of the possible corrosion reactions. Figure 1 shows the E-pH diagram for water with no metal involved. Line (a) represents the equilibrium reaction for hydrogen ions to evolve hydrogen gas (see Equation 2). At any potential and $\mathrm{pH}$ below this line the hydrogen ion in water will react with electrons to evolve hydrogen gas. Line (b) represents the equilibrium of oxygen plus hydrogen ions to form water (see Equation 3).

$\mathrm{O}_{2}+4 \mathrm{H}^{+}+4 \mathrm{e}^{-} \longrightarrow 2 \mathrm{H}_{2} \mathrm{O}$

At any potential and $\mathrm{pH}$ above this line water is oxidized to evolve oxygen gas and hydrogen ions (the reverse of Equation (3)). For potential and $\mathrm{pH}$ conditions between lines (a) and (b), water is thermodynamically stable and there is no gas evolved. 


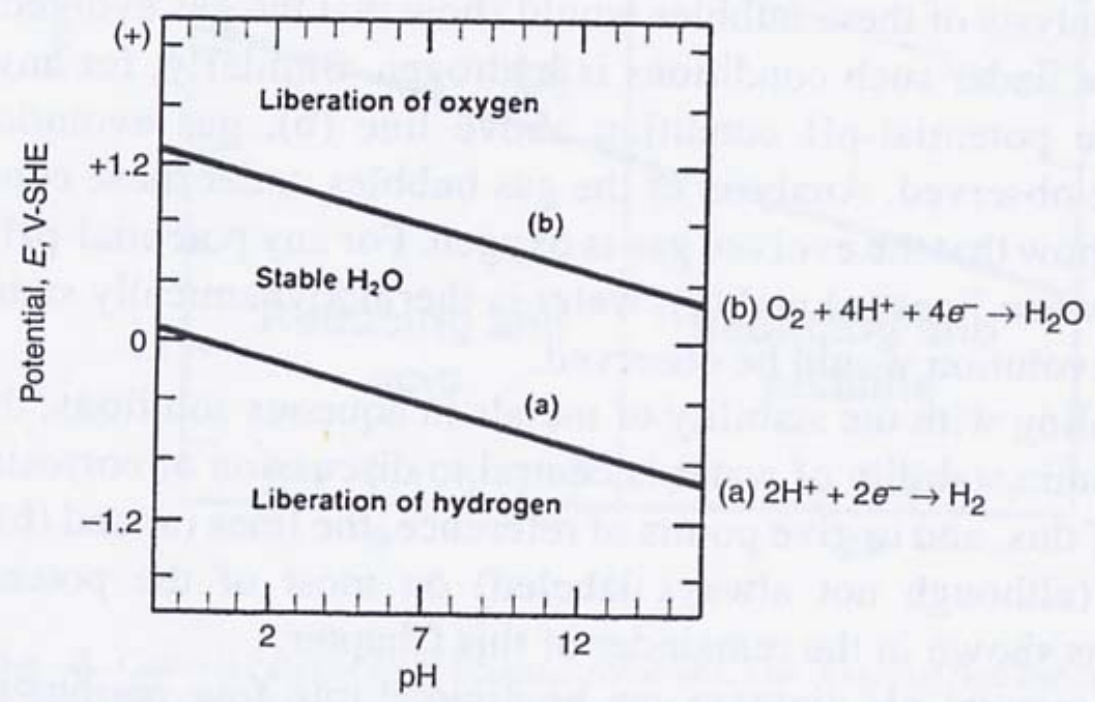

Figure 1. Pourbaix diagram for water [2].

Figure 2 shows the Pourbaix diagram for iron in an aqueous environment. The diagram shows the regions of stability for iron, the ferrous ion $\left(\mathrm{Fe}^{2+}\right)$, the ferric ion $\left(\mathrm{Fe}^{3+}\right)$, and the oxides that make up the corrosion products. The double lines separate species related by redox equilibria for iron and/or its oxidized species or corrosion product. The double line representing the corrosion of iron to ferrous ion (Equation 1) is highlighted, as is the dashed line (f), which represents the hydrogen evolution reaction (Equation 2). Therefore from the diagram it may be concluded that hydrogen evolution is accompanied by the corrosion of iron to ferrous species. The sum of Equations (1) and (2) show that the molar ratio of hydrogen evolved to iron corroded is $1: 1$.

$\mathrm{Fe}^{\circ}+2 \mathrm{H}^{+} \longrightarrow \mathrm{Fe}^{2+}+\mathrm{H}_{2} \uparrow$

On the other hand the diagram shows that the ferric ion is only stable above a potential of $0.77 \mathrm{~V}$ vs. NHE. Thus the ion is only stable in regions where water is stable (between lines (d) and (f)) or oxygen is evolved (above line (d)). This diagram also shows that the direct oxidation of iron to ferric ions does not occur. Ferric ion could form in the presence of an oxidizing species such as oxygen. This redox process, which involves the ferrous ion, is described in Equations (5) through (7).

$\mathrm{Fe}^{2+} \longrightarrow \mathrm{Fe}^{3+}+\mathrm{e}^{-}$

$\mathrm{O}_{2}+4 \mathrm{H}^{+}+4 \mathrm{e}^{-} \longrightarrow 2 \mathrm{H}_{2} \mathrm{O}$

$\overline{4 \mathrm{Fe}^{2+}+\mathrm{O}_{2}+4 \mathrm{H}^{+} \longrightarrow 4 \mathrm{Fe}^{3+}+2 \mathrm{H}_{2} \mathrm{O}}$




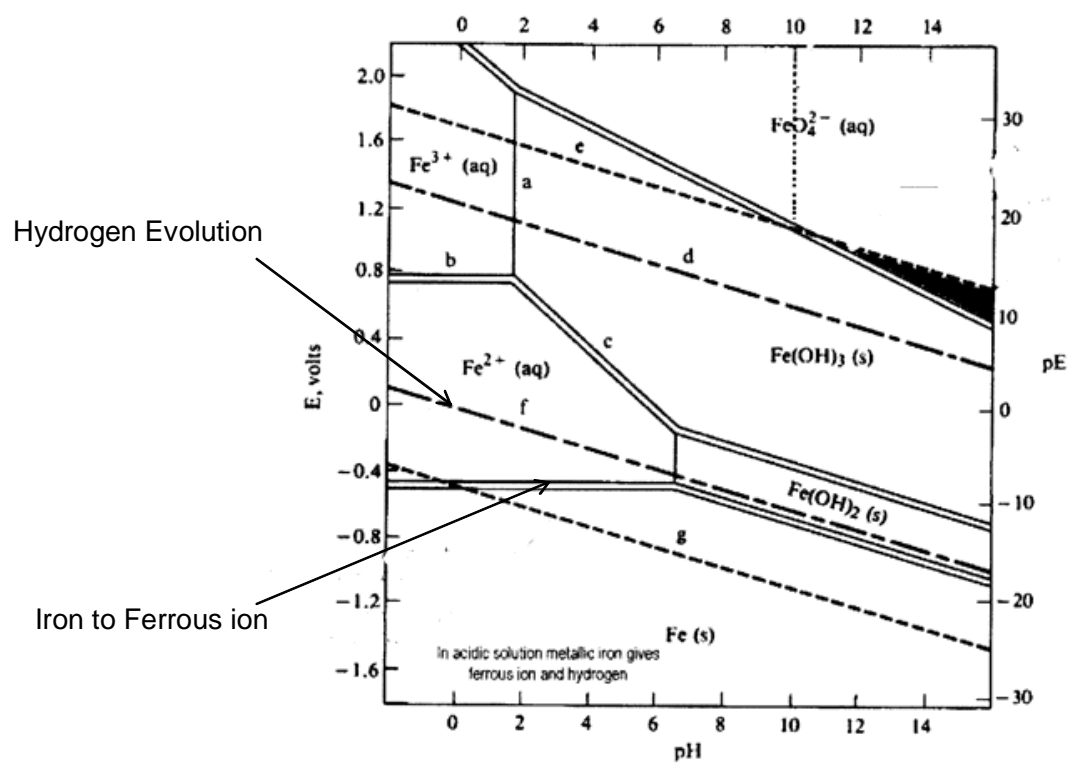

Figure 2. Pourbaix diagram for iron and water [3].

One of the weaknesses of the standard Pourbaix diagram is that it does not account for the presence of other ionic species in solution. Advances and extensions of the diagrams have been made to include other ionic species. The diagram for iron-oxalic acid-water is shown in Figure 3 [4]. Two features have been added to the iron-water diagram. The first feature describes the dissociation of the oxalic acid into the hydro-oxalate $\left(\mathrm{HC}_{2} \mathrm{O}_{4}{ }^{-}\right)$ and oxalate species (see solid red lines on diagram). The distribution of species for oxalic acid is shown in Figure 4 [4]. At a $\mathrm{pH}<1.25$ oxalic acid is the primary species, while at a $\mathrm{pH}$ between 1.25 and 4, the hydro-oxalate species is predominant. For $\mathrm{pH}$ greater than 4 , the oxalate species is most stable species. The second feature is the region of stability for the ferrous oxalate species indicated by the cross-hatched area. This area is defined by the following electrochemical reactions.

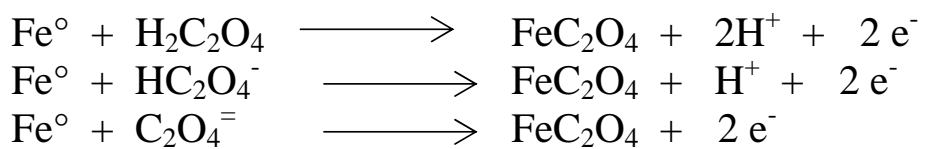

A $1 \mathrm{M}$ oxalic acid solution ( 9 wt.\%) has a pH of approximately 0.83 [5]. In this case the solution would be approximately $73 \%$ undissociated oxalic acid and $27 \%$ hydro-oxalate. Thus Equation (8) and/or (9) may be occurring at the metal surface to form the ferrous oxalate film. These equations may also be working in parallel with the iron dissolution reaction, Equation (1) [6]. 


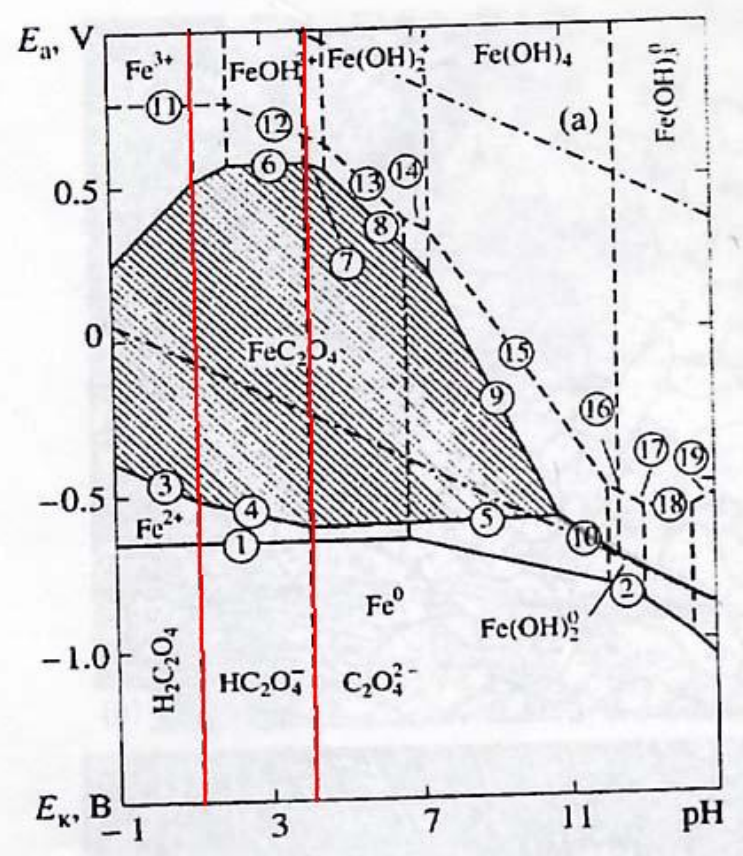

Figure 3. Iron-Oxalic Acid-Water Pourbaix Diagram [6].

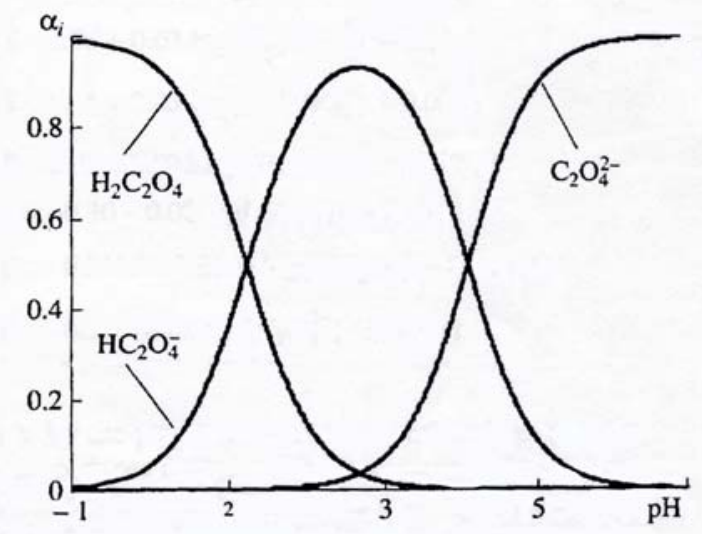

Figure 4. Distribution of oxalic acid species [4].

The hydrogen evolution reaction is determined by Equation (2). However, as discussed previously, several anodic reactions have been proposed. These reactions could occur by themselves or occur simultaneously. Electrochemical laboratory tests have been utilized to determine the anodic reaction mechanism [4-12]. The details of the conditions of these tests and supporting results will be described in section 4. Earlier references inferred from the test results that the anodic reaction was simply iron corroding to form ferrous ion [5, 7-12]. However, the more recent electrochemical tests [4, 7] indicate that the hydro-oxalate species also participates in the corrosion reaction as shown in Equation (9) along with the iron oxidation reaction in Equation (1). Equation (11) is the sum of reactions (1) and (9). 
$\mathrm{Fe}^{\circ}+1 / 2 \mathrm{HC}_{2} \mathrm{O}_{4}^{-} \longrightarrow 1 / 2 \mathrm{FeC}_{2} \mathrm{O}_{4}+1 / 2 \mathrm{Fe}^{2+}+1 / 2 \mathrm{H}^{+}+2 \mathrm{e}^{-}$

Equation (12) is the sum of the anodic (equation (2)) and cathodic (equation (11)) reactions.

$\mathrm{Fe}^{\circ}+1 / 2 \mathrm{HC}_{2} \mathrm{O}_{4}^{-}+3 / 2 \mathrm{H}^{+} \longrightarrow 1 / 2 \mathrm{FeC}_{2} \mathrm{O}_{4}+1 / 2 \mathrm{Fe}^{2+}+\mathrm{H}_{2} \uparrow$

Thus even the more recent studies would confirm that the ratio of hydrogen evolved to iron corroded would be 1:1.

Another reference proposed that iron is oxidized directly to the ferric ion [13]. This mechanism was proposed based on corrosion coupon tests and measurement of the hydrogen evolved during the test.

$\mathrm{Fe}^{\circ} \longrightarrow \mathrm{Fe}^{3+}+3 \mathrm{e}^{-}$

Again the cathodic reaction was Equation (2). The sum of equations (13) and (2) gives:

$2 \mathrm{Fe}^{\circ}+6 \mathrm{H}^{+} \longrightarrow 2 \mathrm{Fe}^{3+}+3 \mathrm{H}_{2} \uparrow$

Based on this equation the ratio of hydrogen evolved to iron corroded would be $1.5: 1$. However, from the previous theoretical discussion on the iron-water and iron-oxalic acidwater Pourbaix diagrams Equation (13) is not thermodynamically possible. The test conditions and results will be examined critically in Section 4 to determine if the mechanisms described in other references could describe the observed results.

\subsection{Experimental Studies}

The results of the experimental studies are critically examined in this section. The first sections examine the electrochemical tests that were performed to investigate the anodic reaction [4-12]. The final section looks at the experimental work that was intended to measure the hydrogen evolved during corrosion of carbon steel in $8 \mathrm{wt}$ \% oxalic acid. These tests covered a wide range of environments as shown in Table 1. A detailed summary of all the results will not be presented. However, those results that are pertinent to the anticipated SRS chemical cleaning environment and also those that reveal the character of the anodic reaction(s) are examined.

\subsection{Open Circuit Potential Measurements}

The open circuit potential (Eoc) is the steady state potential at which a metal equilibrates in a given environment (i.e., there is no external source polarizing or shifting the potential from the equilibrium value). The test is performed by immersing the metal in the solution and monitoring the potential with time. The Eoc is determined when the potential becomes constant with respect to time. The Eoc coupled with the $\mathrm{pH}$ can be 
mapped to the Pourbaix diagram to determine the thermodynamic stability of a species as well as to determine which reactions are possible.

\section{Table 1. Laboratory Testing Environments}

\begin{tabular}{|c|c|c|c|c|c|}
\hline Tests Performed & $\begin{array}{l}\text { Solution } \\
\text { Composition }\end{array}$ & Temperature & Aeration/Stirring & $\mathrm{pH}$ & Reference \\
\hline $\begin{array}{l}\text { Open Circuit } \\
\text { Potential, Anodic } \\
\text { Polarization }\end{array}$ & $\begin{array}{l}\text { Various } \\
\text { solutions of } \\
\text { oxalic acid + } \\
\text { potassium } \\
\text { oxalate with a } \\
\text { constant ionic } \\
\text { strength of } \\
0.48^{\text {(a) }}\end{array}$ & Ambient & De-aerated & $1.25-5.2$ & 4 \\
\hline $\begin{array}{l}\text { Open Circuit } \\
\text { Potential, Anodic } \\
\text { Polarization, } \\
\text { Impedance } \\
\text { Spectroscopy, X- } \\
\text { ray Diffraction }\end{array}$ & $\begin{array}{l}0.5 \mathrm{M} \text { oxalic } \\
\text { acid }\end{array}$ & Ambient & De-aerated & $1.0^{(\mathrm{b})}$ & 5 \\
\hline $\begin{array}{l}\text { Open Circuit } \\
\text { Potential, Anodic } \\
\text { Polarization }\end{array}$ & $\begin{array}{l}\text { Various } \\
\text { solutions of } \\
\text { oxalic acid + } \\
\text { potassium } \\
\text { oxalate with a } \\
\text { constant ionic } \\
\text { strength of } \\
0.48^{\text {a) }}\end{array}$ & Ambient & De-aerated & $1.25-5.2$ & 6 \\
\hline $\begin{array}{l}\text { Open Circuit } \\
\text { Potential, Anodic } \\
\text { Polarization, } \\
\text { Potentiostatic, } \\
\text { Coupon Tests }\end{array}$ & $\begin{array}{l}0.1 \text { to } 0.7 \mathrm{M} \\
\text { Oxalic Acid, } \\
\text { Reagent and } \\
\text { Technical Grade }\end{array}$ & 22 and $50^{\circ} \mathrm{C}$ & $\begin{array}{l}\text { Aerated, Aerated } \\
\text { and agitated }\end{array}$ & $0.9-1.2^{(\mathrm{b})}$ & 7 \\
\hline $\begin{array}{l}\text { Open Circuit } \\
\text { Potential, Anodic } \\
\text { Polarization, } \\
\text { Coupon Tests, } \\
\text { XPS Surface } \\
\text { Analysis }\end{array}$ & $\begin{array}{l}0.63 \text { to } 14.5 \\
\text { wt.\% Oxalic } \\
\text { Acid }\end{array}$ & Ambient & De-aerated & $0.5-2.3^{(\mathrm{b})}$ & 8 \\
\hline $\begin{array}{l}\text { Open Circuit } \\
\text { Potential, } \\
\text { Cathodic } \\
\text { Polarization }\end{array}$ & $\begin{array}{l}10^{-5} \text { to } 10^{-1} \mathrm{M} \\
\text { oxalic acid }\end{array}$ & Ambient & De-aerated & $2-6$ & 9 \\
\hline $\begin{array}{l}\text { Open Circuit } \\
\text { Potential, } \\
\text { Cathodic } \\
\text { Polarization }\end{array}$ & $\begin{array}{l}0.05 \mathrm{M} \text { oxalic } \\
\text { acid, Ferrous ion } \\
\text { concentration } \\
\text { from } 0 \text { to } 10^{-3} \mathrm{M}\end{array}$ & Ambient & De-aerated & 2.8 & 11 \\
\hline $\begin{array}{l}\text { Open Circuit } \\
\text { Potential, Anodic } \\
\text { Polarization }\end{array}$ & $\begin{array}{l}0.05 \mathrm{M} \text { oxalic } \\
\text { acid, } 0.05 \mathrm{M} \\
\text { oxalic acid with } \\
\text { nitrate, nitrite, } \\
\text { and chloride ions }\end{array}$ & Ambient & De-aerated & 4.5 & 12 \\
\hline $\begin{array}{l}\text { Corrosion } \\
\text { Coupons, } \\
\text { Hydrogen } \\
\text { Collection }\end{array}$ & $\begin{array}{l}8 \mathrm{wt} \% \% \text { oxalic } \\
\text { acid }\end{array}$ & $50^{\circ} \mathrm{C}$ & $\begin{array}{l}\text { De-aerated, } \\
\text { agitated }^{(c)}\end{array}$ & $0.9^{(\mathrm{b})}$ & 13 \\
\hline
\end{tabular}

(a) Molarity of solution is not known exactly, however it is estimated to be approximately $0.16 \mathrm{M}$.

(b) $\mathrm{pH}$ was estimated from the oxalic acid concentration.

(c) Sweep gas contained up to $50 \mathrm{ppm}$ air. 
Figure 5 shows the Eoc versus time plots for carbon steel in various oxalic acid solutions at ambient temperatures [8]. The Eoc ranged between -0.45 to $-0.50 \mathrm{~V}$ vs. the saturated calomel reference electrode (SCE) and becomes slightly more positive as the oxalic acid concentration increases. In order to map these potentials to the Pourbaix diagram the potential must be translated to the normal hydrogen reference electrode (NHE). This conversion is performed by adding $+0.24 \mathrm{~V}$ from the potential measured versus the SCE. Thus, the open circuit potentials would be in the range of -0.21 to $-0.26 \mathrm{~V}$ vs. NHE. The $\mathrm{pH}$ of the solutions ranges between 0.5 and 2.3. This potential-pH is in the region where the ferrous oxalate precipitate forms, the hydro-oxalate ions are stable, and hydrogen evolves. This result would support a mechanism that proposed equations (4) and (12).

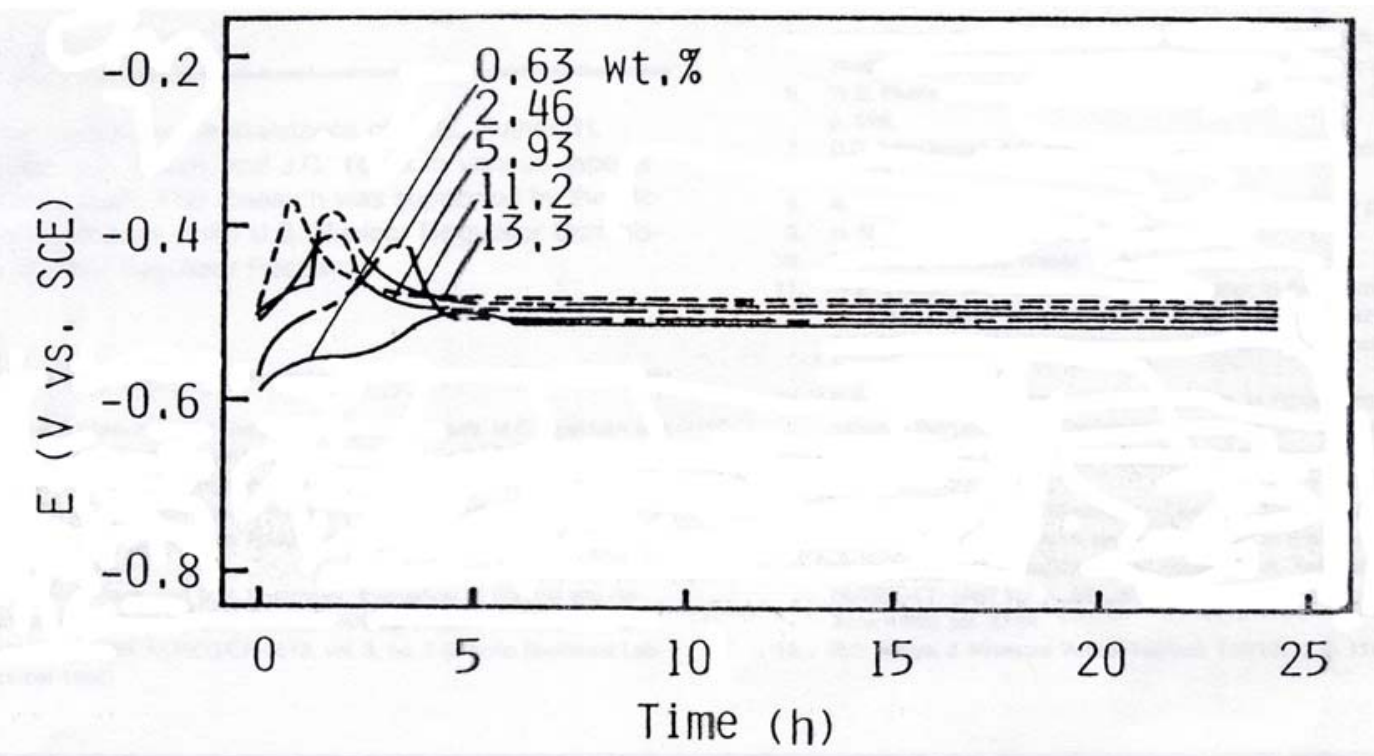

Figure 5. Eoc versus time plot for carbon steel in various oxalic acid solutions at ambient temperature [8].

The Eoc was also measured at $50{ }^{\circ} \mathrm{C}$ in oxalic solutions between 0.1 and $0.7 \mathrm{M}$ [7]. The Eoc was essentially the same as that at ambient temperature indicating that the same anodic and cathodic reactions were occurring. In the same reference Eoc was measured at ambient temperatures in an aerated environment. The Eoc was essentially the same as that in the de-aerated environment [8]. This result suggested that oxygen does not play a significant role in the corrosion reaction (i.e., does not de-polarize the hydrogen evolution reaction).

\subsection{Anodic Polarization}

Anodic polarization involves ramping the potential of the metal at a pre-determined scan rate above the Eoc and measuring the current density response to the change in potential. The current density provides an indication of the rates at which anodic or passivation reactions occur. Current density peaks are usually associated with active dissolution of 
the metal or the oxidation of metal ions in solution at the metal surface, while regions where the current is low and nearly constant are associated with passivation of the surface.

Figure 6 shows an example of an anodic polarization curve for carbon steel in various oxalic acid solutions at ambient temperature [8]. Two current peaks and two current minimums were observed. The first peak, which occurs at approximately $-0.45 \mathrm{~V}$ vs. SCE, has been interpreted to be an indication of the occurrence of reaction (1) or (11). The first minimum region ( -0.3 to $+0.1 \mathrm{~V}$ vs. SCE) is indicative of passivation by the ferrous oxalate precipitate. It was observed that the current density gradually rises with potential, an indication that the ferrous oxalate is an unstable passive film. In addition, the cathodic reaction will change in this region given that the potentials move above the hydrogen evolution line of the Pourbaix diagram (see Figure 3). The second peak that occurs at approximately $+0.2 \mathrm{~V}$ vs. SCE has been interpreted as the representing the oxidation of ferrous ion to ferric ion. Again it is observed that the ferric ion does not appear until the potential is well above the hydrogen evolution line of the Pourbaix diagram (see Figure 3 ). The next minimum region $(+0.5 \mathrm{~V}$ to $1.2 \mathrm{~V})$ represents the formation of an iron oxide on the surface. The iron oxide will typically incorporate the ferric ion, although some ferrous ion may be included. It is interesting to note that the current is fairly constant in this region, indicating a fairly stable oxide film. At potentials greater than $1.2 \mathrm{~V}$ vs. SCE the ferric/ferrous oxide film begins to break down and oxygen is evolved.

Figure 6 also shows that the current density of the first peak does not change significantly with concentration. This observation is in agreement with coupon tests that observed that there was little if any difference in the corrosion rate of carbon steel in $4 \mathrm{wt} . \%$ oxalic acid and $8 \mathrm{wt} . \%$ oxalic acid [14]. In fact in the electrochemical tests the lowest peak potential occurred at the highest concentration ( $14 \mathrm{wt} . \%)$. This observation may correlate with the fact that as the oxalic acid concentration increases the $\mathrm{pH}$ decreases. As a result more of the oxalate species is present and less of the hydro-oxalate species is present. Thus reaction (8) would be more likely than reaction (9). If reaction (8) is significantly slower than reaction (9) a decrease in the current density would be observed. In this region the anodic reactions (1) and (8) are more likely. It is interesting to note that this ferrous oxalate film is less stable than the films formed at lower concentrations (i.e., the current density in the first minimum region is higher). 


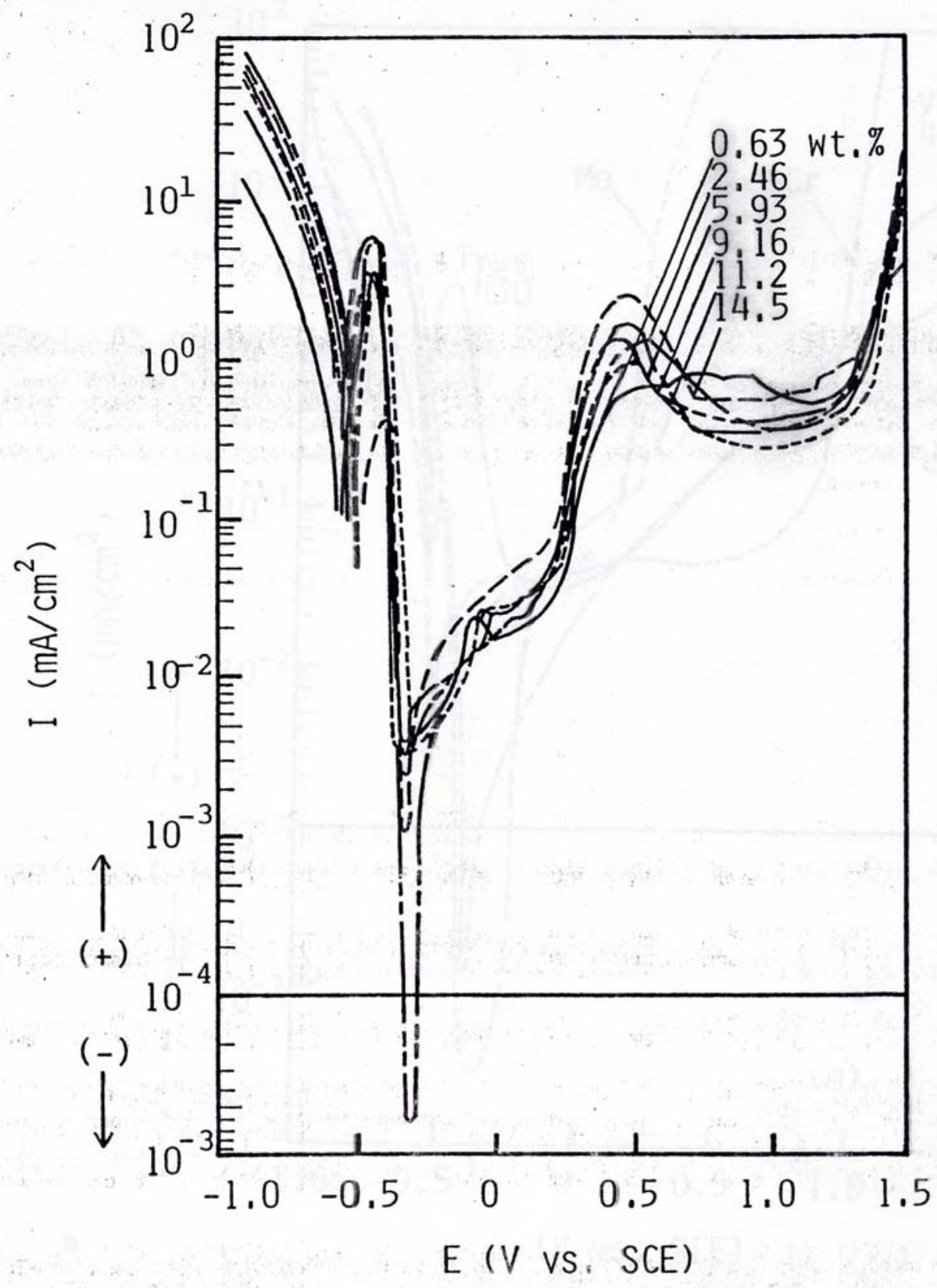

Figure 6. Anodic polarization curve for carbon steel exposed to various compositions of oxalic acid at ambient temperature [8].

The anodic polarization curve for $0.1 \mathrm{M}$ oxalic acid at $50{ }^{\circ} \mathrm{C}$ is shown in Figure 7 [7]. Neither the potential of the first peak current density nor the current density changed significantly from that shown in Figure 6. However, the current density for the minimum region where the passive oxalate film forms is approximately 3 times greater than that for the ambient condition. This observation correlates well with the results of coupon tests that indicate the corrosion rate of carbon steel increases significantly as the temperature increases between 25 and $50{ }^{\circ} \mathrm{C}$ [14]. 


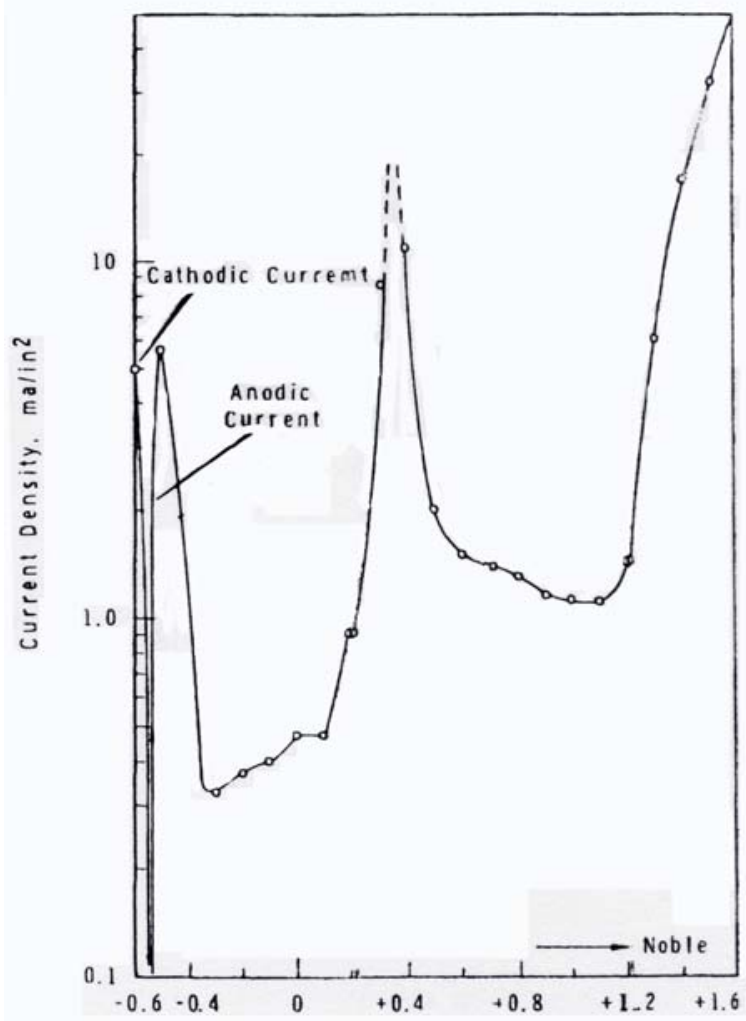

Figure 7. Anodic polarization curve for carbon steel exposed to $0.1 \mathrm{M}$ oxalic acid at $50{ }^{\circ} \mathrm{C}$ in aerated conditions [7].

\subsection{Cathodic Polarization}

Cathodic polarization involves decreasing the potential of the metal at a pre-determined scan rate to below the Eoc and measuring the current density response as a function of the change in potential. The slope of the linear portion of the potential-log current density plot is referred to as the Tafel slope.

In a de-aerated solution, the Tafel slope for the hydrogen evolution reaction is expected to be approximately $120 \mathrm{mV} /$ decade. The results of a cathodic polarization test performed on carbon steel in de-aerated $0.05 \mathrm{M}$ oxalic acid are shown in Figure 8 [11]. The slope of the linear portion of the line was estimated to be approximately 126 $\mathrm{mV} /$ decade. This result confirmed that hydrogen generation is the cathodic reaction. 


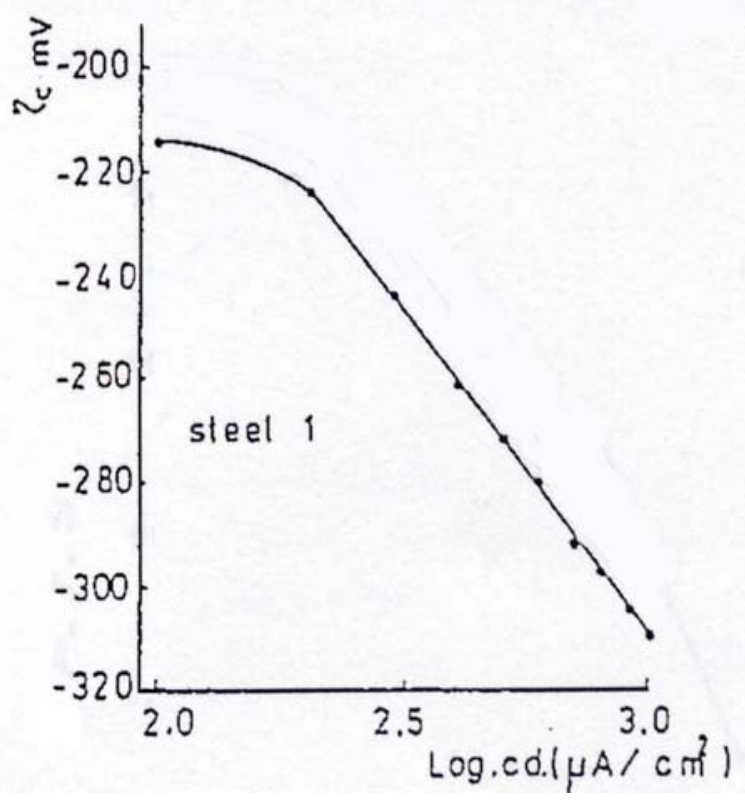

Figure 8. Cathodic polarization of carbon steel exposed to $0.05 \mathrm{M}$ oxalic acid at ambient temperature [11].

No literature references for cathodic polarization studies in an aerated environment were located. If oxygen depolarizes the cathodic reaction, a characteristic limiting current as shown in Figure 9 would appear (i.e., region where the current density does not change with potential) [15]. The anodic polarization scans seemed to indicate that the presence of oxygen had little effect on the metal dissolution behavior. If oxygen has no impact on the cathodic polarization curve behavior, this would mean that hydrogen evolution is still the likely cathodic reaction. Thus even in the presence of oxygen the ratio of moles of hydrogen evolved to moles of iron corroded would be $1: 1$. This hypothesis would need to be confirmed by performing selected cathodic polarization scans in an aerated oxalic acid environment.

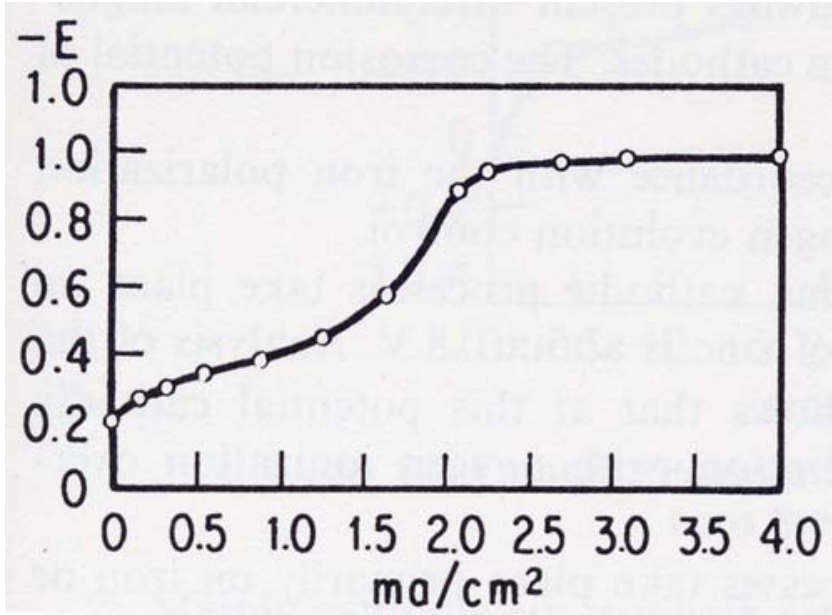

Figure 9. General cathodic polarization curve for oxygen depolarization [15]. 


\subsection{Effect of Agitation}

Coupon tests were performed in non-agitated and agitated solutions [7]. Table 2 shows that the corrosion rate increased in the agitated solution. This observation indicates that the ferrous ion is being removed from the surface where it precipitates with the oxalate species [5]. The lack of a semi-protective ferrous oxalate film on the surface allows the corrosion rate to increase. Although this would not affect the ratio of the moles of hydrogen evolved to moles of iron corroded, the hydrogen evolution rate could increase if the corrosion rate increases.

Table 2. Corrosion rate of carbon steel in room temperature oxalic acid under agitated and non-agitated conditions.

\begin{tabular}{|c|c|c|}
\hline $\begin{array}{l}\text { Concentration } \\
(\mathrm{M})\end{array}$ & $\begin{array}{l}\text { Corrosion Rate } \\
\text { with No } \\
\text { Agitation } \\
\text { (mpy) }\end{array}$ & $\begin{array}{l}\text { Corrosion Rate } \\
\text { with Agitation } \\
\text { (mpy) }\end{array}$ \\
\hline 0.1 & 13 & 46 \\
\hline 0.3 & 20 & 50 \\
\hline
\end{tabular}

\subsection{Analysis of Surface Films and Solution}

A yellow-green precipitate was observed on many of the samples. X-ray diffraction analysis of the film showed that it was primarily ferrous oxalate di-hydrate [5].

An emerald green solution color was noted in one of the coupon tests as well [13]. The green color was attributed to a ferric oxalate complex although no analysis of the solution was noted in the reference. It is interesting to note that the ferrous ion in solution is also a greenish color [1]. The solution in this test was agitated. It is possible that the agitation has removed some of the ferrous ion from near the metal surface and that this results in the greenish color. The presence of any oxygen also would oxidize the ferrous ion to the ferric species [16]. The ferric species would then be available to form the ferric oxalate complex. A small amount of oxygen was observed in the vessel at the completion of these tests. If further coupon tests are performed, it is recommended that the solution be analyzed to verify that the green color occurs.

\subsection{Hydrogen Generation Measurements}

Coupon tests were performed on ASTM A516 carbon steel in $8 \mathrm{wt} . \%$ oxalic acid at $50{ }^{\circ} \mathrm{C}$ under de-aerated conditions [13]. Both clean and rusted steel coupons were utilized for the tests. The hydrogen gas was collected to provide an estimate of the hydrogen generation rate while carbon steel corroded. The coupon weight loss was also measured. The moles of hydrogen generated based on the corrosion rate was compared to the moles of hydrogen collected. It was claimed that the results supported the reaction mechanism predicting 1.5 moles of hydrogen generated for every mole of iron dissolved (see Equation (14)). Since this result was not in agreement with theory and other 
experimental observations the results were reviewed more carefully to determine if there were other explanations.

The hydrogen generation rate was measured during the first two hours and at the end of one week. These two generation rates were then averaged to calculate the average hydrogen generation rate. The average hydrogen generation rate was compared with the corrosion rate to determine the ratio of moles of hydrogen evolved to moles of iron corroded. In general, the hydrogen evolution rate was high initially and then decreased significantly. The range of this ratio for these tests was 1.2 to 3.25. Since the ratio was greater than 1:1, it was claimed as evidence that supported Equation (14).

However, the data analysis assumes that the corrosion rate was constant with time. It is very likely that the corrosion rate was initially rapid before the formation of the oxalate film on the surface. The high corrosion rate would correlate with observance of a high hydrogen evolution rate. No corrosion rate data was collected for the two hour data in order to make this comparison. A separate calculation was performed to estimate the amount of corrosion that would have occurred based on the total hydrogen that evolved during the first 2 hours. If the ratio of hydrogen evolved to iron corroded was $1: 1$, the weight loss on the carbon steel coupon would have been approximately $0.08 \mathrm{~g}$, while for the 1.5:1 ratio the weight loss would have been approximately $0.12 \mathrm{~g}$. Thus approximately $10 \%$ of the total weight loss observed in a week would have occurred during the first two hours. Weight differences such as these could have been measured and would have provided better evidence for the claim.

The reference also claims that the emerald green appearance of the solution confirms the presence of the ferric oxalate complex. However, the reference does not say whether the solution was analyzed. Additionally, as discussed in section 4.5, there are two other mechanisms that could explain the green solution color. Neither of these mechanisms would involve hydrogen evolution. Thus, this result does not provide conclusive evidence for the $1.5: 1$ ratio either.

\subsection{Application of Theory and Experimental Results to Chemical Cleaning Process at SRS}

The conclusion from the above discussion on theory and the experimental evidence is that in a de-aerated oxalic acid-iron system the ratio of moles of hydrogen evolved to moles of iron corroded is $1: 1$. The only way this ratio will change is if oxygen or some other oxidizing species de-polarizes the cathodic reaction such that the ratio will become less than 1:1. The ratio would not be greater than 1:1. Testing in an aerated environment would need to be performed to quantify how much less than 1:1 the ratio might be.

During chemical cleaning certain variables pertinent to the waste tanks impact the total amount of hydrogen that is evolved. Table 3 summarizes the variables and the expected impact on total hydrogen evolved. After reviewing the variables and their impacts it is expected that utilizing corrosion rates from clean samples in pure oxalic acid would be 
the most conservative approach. However, if the use of lower hydrogen generation rates or total hydrogen evolved is desired, further testing to look at these variables is necessary. The testing should include electrochemical and coupon tests. During the coupon tests provisions should be made to collect the hydrogen gas.

Table 3. Impact of actual tank conditions during chemical cleaning on hydrogen evolution.

\begin{tabular}{|c|c|}
\hline Variable & Impact on Hydrogen Evolved \\
\hline Radiation [17] & $\begin{array}{l}\text { Gamma radiation promotes recombination } \\
\text { reactions that suppress hydrogen evolution. }\end{array}$ \\
\hline Sludge Heel & $\begin{array}{l}\text { 1. Sludge heel will initially hinder } \\
\text { direct contact between the oxalic } \\
\text { acid and the carbon steel tank } \\
\text { bottom. This reduces the exposed } \\
\text { surface area and hence the total } \\
\text { hydrogen evolved. } \\
\text { 2. Oxalic acid reacts with the oxides } \\
\text { in the sludge [18]. No excess } \\
\text { hydrogen is expected from this } \\
\text { reaction. }\end{array}$ \\
\hline Corrosion Products on Tank Steel & $\begin{array}{l}\text { Initially the iron oxide is expected to be } \\
\text { protective, however, over time the oxalic } \\
\text { acid will break down the corrosion } \\
\text { products and corrosion will then proceed. } \\
\text { The initial burst of hydrogen observed on } \\
\text { the clean coupon in reference } 13 \text { would not } \\
\text { be expected for the corroded tank wall. }\end{array}$ \\
\hline Other anions & $\begin{array}{l}\text { The effects of other anions have led to } \\
\text { some unexplained corrosion rate results } \\
\text { [14]. Electrochemical tests suggests that } \\
\text { the anions interfere with build-up of the } \\
\text { passive ferrous oxalate layer [12]. Thus the } \\
\text { corrosion rate was slightly higher. It is not } \\
\text { know if these anions such as nitrate and } \\
\text { nitrite participate in the cathodic reaction or } \\
\text { if hydrogen is still primarily involved. }\end{array}$ \\
\hline
\end{tabular}

\subsection{Conclusions}

A literature review of the corrosion mechanism for iron in oxalic acid solutions was performed to determine the ratio of moles of iron corroded to moles of hydrogen evolved. The maximum ratio of moles of hydrogen evolved to moles of iron corroded is $1: 1$, which would be observed in a de-aerated environment. If oxygen or other oxidizing species are 
present, the ratio would be less than 1:1. If the use of lower hydrogen generation rates or total hydrogen evolved is desired, further testing to look at these variables is necessary. The testing should include electrochemical and coupon tests. During the coupon tests provisions should be made to collect the hydrogen gas.

\subsection{References}

1. Atlas of Electrochemical Equilibria in Aqueous Solutions, Ed. by M. Pourbaix, NACE International, Houston TX, p. 317, 1974.

2. Corrosion: Understanding the Basics, Ed. by J. R. Davis, ASM International, Metals Park, OH, p. 63, 2000.

3. Information from the website http://www/wou.edu/las/physci/ch412/pourbaix.htm.

4. S. N. Saltykov, et. al, “Anodic Behavior of White Iron Phases in Oxalic Media”, Protection of Metals, Vol. 40, No. 1, pp. 56-61, 2004.

5. L. A. Sokolova, et. al., "The Passivation of Iron in Oxalate Solutions”, Protection of Metals, Vol. 12, No.2, pp. 145-153, 1976.

6. S. N. Saltykov, "A Mechanism of the Anodic Dissolution of Armco Iron and High Strength Ferritic Cast Iron in an Oxalate Medium”, Protection of Metals, Vol. 37, No. 2, pp. 186-191, 2001.

7. L. D. Perrigo, “Anodic Protection of Carbon Steel in Oxalic Acid”, Materials Protection, pp. 73-76, March, 1966.

8. I. Sekine and C. Okano, "Corrosion Behavior of Mild Steel and Ferritic Stainless Steels in Oxalic Acid Solution”, Corrosion, Vol. 45, No. 11, pp. 924-932, 1989.

9. V. K. Gouda, et. al., "The Corrosion Behavior in Organic Acid Solutions - II. A Steel Electrode”, Corrosion Science, Vol. 20, pp. 1091-1099, 1980.

10. M. A. Streicher, "Synergistic Inhibition of Ferric Ion Corrosion During Chemical Cleaning of Metal Surfaces”, Corrosion, Vol. 28, No. 4, p. 143, April, 1972.

11. M. S. Abdel Aal, et. al., "Influence of Fe2+ ion on the Corrosion of Carbon Steel", Materials Chemistry and Physics, Vol 39, pp. 290-297, 1995.

12. M. S. Abdel Aal, et. al., "Anodic Behavior of Mild Steel in Deaerated Carboxylic Acid Solutions Containing $\mathrm{NO}_{2}{ }^{-}, \mathrm{Cl}^{-}$, and $\mathrm{NO}_{3}{ }^{-}$Ions”, Br. Corr. J., Vol. 16, No. 4, 1981.

13. H. D. Smith, R. L. Russell, and G. K. Patello, “Evaluation of Hydrogen Gas Generation from Oxalic Acid Contact with the Carbon Steel of a High Level Waste Storage Tank,” In Environmental Issues and Waste Management Technologies in the Ceramic and Nuclear Industries, Eds. J. C. Marra and G. T. Chandler, Ceramic Transactions, Vol. 93, pp. 221-227, 1999.

14. M. R. Elmore, “Corrosion of Mild Steel in Simulated Cesium Elution Process Solutions”, PNNL-11284, September, 1996.

15. Theory of Corrosion and Protection of Metals, N. D. Tomashov, The MacMillan Company, New York, p. 199, 1966.

16. Information from the website http://www.uncp.edu/home/mcclurem/ptable/iron/fe.htm.

17. D. W. Vinson, et, al., "Evaluation of Hydrogen Generation from Radiolysis from Breached Fuel”, WSRC-MS-2002-00728, September, 2002. 
18. N. E. Bibler, " $\mathrm{H}_{2} \mathrm{O}_{2}-\mathrm{H}_{2} \mathrm{C}_{2} \mathrm{O}_{4}$ Solutions for Cleaning Inside Surfaces of SRP Waste Tanks”, DPST-81-308, March 10, 1981.

19. B. J. Wiersma, “Corrosion Mechanisms and Rates for Carbon Steel and Stainless Steel Materials Exposed to Oxalic Acid Solutions”, WSRC-TR-2004-00109, March, 2004. 